\title{
Can Neutrophil/Lymphocyte and Platelet/Lymphocyte Rates Predict Bone Metastasis in Prostate Cancer Patients?
}

\author{
Nötrofil/Lenfosit ve Trombosit/Lenfosit Oranları Prostat Kanseri Olgularında Kemik \\ Metastazını Öngörebilir mi?
}

\author{
(D) Yeşim Ceylan1, (D) Sevil Tatlıdil2, (D) Sait Şen³, (D) Banu Sarsık³, (D) Zehra Özcan² \\ ${ }^{1}$ Adıyaman Training and Research Hospital, Clinic of Nuclear Medicine, Adıyaman, Turkiye \\ 2Ege University Training and Research Hospital, Department of Nuclear Medicine, Izmir, Turkiye \\ ${ }^{3}$ Ege University Faculty of Medicine, Department of Pathology Izmir, Turkiye
}

\section{What's known on the subject? and What does the study add?}

Some recent studies have showed that inflammatory response is an important component in the development and progression of malignant tumors. It has been also documented that an elevated NLR is linked to progressive disease and poor overall survival in tumors of breast, colon and urinary system. In our study, we found high NLR values in patients with scintigraphic bone metastasis, and we have achieved results that support recent studies.

\section{Abstract}

Objective: Bone metastasis is common in advanced prostate cancer (PCa). Recently, there has been a growing interest in the potential role of inflammatory markers, such as neutrophil-to-lymphocyte ratio (NLR), platelet-to-lymphocyte ratio (PLR) and neutrophil-to-monocyte ratio (NMR), in predicting advanced disease in patients with solid tumors. In the current study, we aimed to assess the relationship of bone metastasis detected on bone scintigraphy (BS) with NLR, PLR, and NMR in patients with Pca.

Materials and Methods: The study group included 85 PCa patients. Patient characteristics, prostate-specific antigen (PSA) values, Gleason score, histopathological features, presence of metastatic focus on BS and complete blood count values were retrospectively evaluated. The relationship of the presence of bone metastasis on BS with clinicopathological features such as PSA, Gleason score, histopathological findings and NLR, PLR and NMR values were investigated.

Results: Median NLR, PLR and NMR were 2.90, 125.69 and 8.38, respectively. Thirty-six patients had metastatic disease on BS. Our findings showed a statistically significant relationship between high NLR value and the presence of bone metastasis $(p=0.018)$ and high Gleason score $(p=0.034)$. However, no significant statistical relationship was found between clinicopathological features and PLR and NMR values ( $p>0.05$ ).

Conclusion: Despite the limited number of patients, a significant relationship between high NLR and metastatic bone disease was found. While high NLR has been generally considered an independent risk factor for poor PCa prognosis, we assume that larger scale studies are warranted to assess its value as a prognostic indicator in PCa patients.

Keywords: Bone scintigraphy, Prostate carcinoma, Neutrophil-to-lymphocyte ratio, NLR, Platelet-to-lymphocyte ratio, PLR, Neutrophil to monocyte ratio, NMR

\section{Öz}

Amaç: Illeri prostat kanserinde (PCa) kemik metastazı yaygın olarak görülmektedir. Son zamanlarda, solid tümörlerde ilerlemiş hastalığın öngörülmesinde nötrofil lenfosit oranı (NLR), trombosit lenfosit oranı (PLR) ve nötrofil monosit oranı (NMR) gibi enflamatuvar belirteçlerin potansiyel rolüne olan ilgi artmıştır. Bu çalışmada, PCa'da kemik sintigrafisinde (KS) saptanan kemik metastazları ile NLR, PLR ve NMR arasındaki ilişkiyi değerlendirmeyi amaçladık.

Gereç ve Yöntem: Çalışma grubunu 85 PCa hastası oluşturdu. Hastaların özellikleri, prostat spesifik antijen (PSA) değerleri, Gleason skoru, histopatolojik özellikleri, KS'de metastatik odak varlığı ve tam kan sayımı retrospektif olarak incelendi. KS'de kemik metastazı varlığı, PSA, Gleason

Correspondence: Yeşim Ceylan MD, Adıyaman Training and Research Hospital, Clinic of Nuclear Medicine, Adıyaman, Turkiye Phone: +90 5077071889 E-mail: dryesimceylan@gmail.com ORCID-ID: orcid.org/0000-0002-9677-5307

Received: 12.09 .2018

Accepted: 11.12 .2018

Cite this article as: Ceylan Y, Tatlıdil S, Sen S, Sarsık B, Özcan Z. Can Neutrophil/Lymphocyte and Platelet/Lymphocyte Rates Predict Bone Metastasis in Prostate Cancer Patients? J Urol Surg 2019;6(2):105-110.

๑Copyright 2019 by the Association of Urological Surgery / Journal of Urological Surgery published by Galenos Publishing House. 
skoru, histopatolojik bulgular gibi klinikopatolojik özellikler ile NLR, PLR ve NMR değerleri arasındaki ilişki araştırıldı.

Bulgular: Medyan NLR, PLR ve NMR sırasıyla 2,90, 125,69 ve 8,38 idi. Otuz altı hastada KS'de metastatik hastalık vardı. Bulgularımız yüksek NLR değeri ile kemik metastazı varlığı $(p=0.018)$ ve yüksek Gleason skoru arasında istatistiksel olarak anlamlı bir ilişki olduğunu gösterdi ( $p=0,034)$. Ancak PLR ve NMR ile klinikopatolojik özellikler arasında anlamlı istatistiksel ilişki bulunamadı $(p>0,05)$.

Sonuç: Sınırlı hasta sayısına rağmen, yüksek NLR ve metastatik kemik hastalığı arasında anlamlı ilişki bulundu. NLR genel olarak prostat kanseri prognozu için bağımsız bir risk faktörü olarak kabul edilirken, bu hasta grubunda prognostik bir belirteç olarak kabul edilmesi için daha kapsamlı çalışmaların yapılmasının gerekli olduğunu düşünüyoruz.

Anahtar Kelimeler: Kemik sintigrafisi, Prostat kanseri, Nötrofil lenfosit oranı, NLR, Trombosit lenfosit oranı, PLR, Nötrofil monosit oranı, NMR

\section{Introduction}

Some recent studies have showed that inflammatory response is an important component in the development and progression of malignant tumors (1). Therefore, there is a growing interest in assessment of the potential role of biologic markers of systemic inflammatory response such as neutrophil-to-lymphocyte ratio (NLR) in a variety of tumors (2). It has been also documented that an elevated NLR is linked to progressive disease and poor overall survival in tumors of breast, colon and urinary system (3). Cancer progression is associated with neutrophils and cytokines such as tumor necrosis factor alpha, IL1, and IL6. Also platelets play a role with vascular endothelial growth factor (VEGF) which is involved in angiogenesis (4).

Histologic and epidemiological studies also have indicated that infection and inflammation were important in prostate cancer (PCa) development (5). Inflammation may play a role in prostate carcinogenesis via a variety of mechanisms; causing cellular and genomic damage, promoting cellular turnover; cell replication, angiogenesis, and forming a tissue microenvironment inducing tissue repair (6). It has been suggested that NLR, which is an inflammatory marker playing a role in prognosis and development of $\mathrm{PCa}$, is also an independent predictor of survival in newly developed treatment modalities such as radium 223. (7). With progression of the disease, bone metastases alter the integrity of the skeletal system leading to pathological bone fractures and bone pain, which affects the quality of life of the patient. At the time of distant metastasis, the 5-year survival rate is only approximately $30 \%$ (8). In the current study, we aimed to investigate the role of NLR, platelet-to-lymphocyte ratio (PLR) and neutrophil-to-monocyte ratio (NMR) in $\mathrm{PCa}$ patients.

\section{Materials and Methods}

Patients: Patients, who underwent bone scintigraphy due to PCa in the department of nuclear medicine in Ege University and Adıyaman University Training and Research Hospital between March 2015 and January 2017, were examined retrospectively. For this study, approval (17-12.1/36) was obtained from the Ege University Medical Faculty Clinical Research Ethics Committee.
Eighty-five patients (65 from Ege University, 20 from Adıyaman University) were included in the study. All surgical specimens were examined in detail for certain pathologic features including presence of extraprostatic invasion, perineural invasion, positive surgical margin, seminal vesicle invasion and Gleason score. Those with a detailed histopathology report, prostate-specific antigen (PSA) value and complete blood count obtained 1 week prior to scan were selected. We formed 2 cohort groups according to the values above and below the median values of NLR, PLR and NMR. Hematologic indices, PSA values, Gleason score, and presence of metastatic focus on bone scintigraphy (BS) were retrospectively analyzed. Patients with active infection, autoimmune-hematologic disease, chronic steroid use and those with multiple neoplasms were excluded.

Laboratory assessment: Complete blood count was obtained using a Cell-Dyn Ruby hematology analyzer. The NLR was calculated by dividing absolute neutrophil count by the absolute lymphocyte count; similarly, the PLR was calculated by dividing the absolute platelet count by the absolute lymphocyte count, and the NMR was calculated by dividing the absolute monocyte count by the absolute lymphocyte count.

Bone scintigraphy: The patients received an intravenous injection of 540-740 MBq Technetium-99m (99mTc) methylene diphosphonate. Approximately 3 hours later, they underwent a whole-body planar imaging in the anterior and posterior views on a dual-headed gamma camera (Infinia II GP \& Hawkeye 4) fitted with a low-energy, all-purpose, parallel-hole collimator. The photopeak of $99 \mathrm{mTc}$ was $140 \mathrm{keV}$ with a $10 \%$ pulse height analyzer window. If necessary, spot planar images and single photon emission computerized tomography (SPECT) images were obtained. SPECT/CT images were also available in 20 patients. Scintigraphic images were assessed by two experienced nuclear medicine physicians unaware of each other. Patients with abnormal bone findings were considered metastatic when those were supported by clinical/radiologic data. The patients were then divided into two groups according to presence of metastatic abnormal findings on BS.

\section{Statistical Analysis}

Statistical analyzes were performed using SPSS (Statistical Package for Social Sciences) 15.0 (SPSS Inc. Chicago, IL, USA). 
Normal distribution of the data was tested by the KolmogorovSmirnov test. The relationship between the nominal variables was compared with the chi-square test. A p value of less than 0.05 was considered statistically significant.

\section{Results}

A total of 85 patients aged $52-86$ years, who met the study criteria, were included in the study. The mean age of the patients was $68.5 \pm 8.58$ years. Metastatic bone disease was detected on BS in 36 patients; 31 of 36 patients had multifocal bone metastases. No evidence of metastatic involvement was found in 49 patients.

The mean values of NLR, PLR and NMR in the whole group were $3.09 \pm 1.47,158.43 \pm 99.9$, and $8.40 \pm 3.13$, median values were $2.92,125.69$ and 8.38 , respectively. We formed 2 cohort groups according to the values above and below the median value of NLR, PLR and NMR. The two groups were divided according to NLR, PLR and NMR median values and when the relationship between BS findings and clinicopathological features such as PSA, Gleason score, extraprostatic extension, seminal vesicle invasion, surgical border positivity, perineural invasion were analyzed, a statistically significant relationship was found between high NLR value and presence of bone metastasis on BS $(p=0.018$, Table 1$)$ and high Gleason score $(p=0.034)$. There was no statistically significant correlation between PLR (Table 2) and NMR values and clinicopathological features ( $p>0.05$, Table 3 ).

\section{Discussion}

In recent years there have been studies showing that inflammation and cancer pathogenesis were closely related $(4,9)$. Several studies have reported a relationship between inflammatory markers such as NLR, PLR, CRP and the stage of disease, prognosis, and survival (10). NLR, PLR, and NMR can be easily detected by complete blood count which is widely available, simple and inexpensive test. Neutrophils produce proangiogenic factors such as VEGF, matrix metalloproteinase, interleukin-8 and elastases, all of which play a role in tumor angiogenesis (11). These types of cytokines promote tumor growth, development, and metastasis. Platelets also form important compartments for circulating VEGF (11). On the other hand, lymphocytes are related with antitumor immunity (12). Therefore, increased number of lymphocytes in solid tumors considered to be a good prognostic factor (13).

NLR is a prognostic factor in urological malignancies such as bladder cancer, ureter cancer, renal cell carcinoma and PCa $(14,15,16,17)$. Sonpavde et al. (18) found that NLR was closely related to PCa metastases and considered a NLR $\geq 5$ a poor prognostic factor $(p=0.018)$. Wang et al. (19) found that a high
NLR (NLR>3) was associated with poor prognosis in 497 patient with primary malignancies (lung, uterus, breast, thyroid, GIS) with bone metastasis. We also found that bone metastasis was associated with high NLR. When we analyzed PSA values and the histopathological features (perineural invasion, surgical margin positivity, extraprostatic spread, seminal vesicle invasion, and Gleason score) with high NLR, there was a relationship between high NLR and Gleason score. Contrary to our cohort; Maeda and colleagues found no association between NLR and Gleason score and other histopathological features in their study covering 73 patients (20). PLR independently predicts poor prognosis in patients with conditions including gastric cancer, pancreatic cancer, ovarian cancer, colorectal cancer, non-small cell lung cancer, hepatocellular carcinoma, renal cell cancer, and esophageal cancer (16).

Li et al. (21) reported that high PLR values were associated with a high 3-year mortality rate when they have chosen 150 as a cut off value for PLR in a study group of 103 patients with PCa. Kaynar et al. (22) and Yüksel et al. (23) and colleagues

Table 1. Association of preoperative neutrophil to lymphocyte ratio with clinicopathological characteristics and bone metastases of prostate cancer

\begin{tabular}{|c|c|c|c|c|}
\hline & Total $(n=85)$ & $N L R<2.9$ & $N L R \geq 2.9$ & $\mathrm{p}$ \\
\hline \multicolumn{5}{|c|}{ Bone scintigraphy } \\
\hline+ & $36(42.4 \%)$ & $13(30.2 \%)$ & $23(25.6 \%)$ & 0.018 \\
\hline- & $49(57.6 \%)$ & $30(69.8 \%)$ & $19(74.4 \%)$ & \\
\hline \multicolumn{5}{|c|}{ Extraprostatic invasion } \\
\hline+ & $24(28.2 \%)$ & $13(30.2 \%)$ & $11(26.2 \%)$ & 0.49 \\
\hline- & $61(71.8 \%)$ & $30(69.8 \%)$ & $31(73.8 \%)$ & \\
\hline \multicolumn{5}{|c|}{ Perineural invasion } \\
\hline+ & $50(58.8 \%)$ & $25(58.1 \%)$ & $25(59.5 \%)$ & 0.69 \\
\hline- & $35(41.2 \%)$ & $18(41.9 \%)$ & $17(40.5 \%)$ & \\
\hline \multicolumn{5}{|c|}{ Positive resection margin } \\
\hline+ & $13(15.3 \%)$ & $9(21 \%)$ & $4(9.5 \%)$ & 0.10 \\
\hline- & $72(84.7 \%)$ & $34(79 \%)$ & $38(80.5 \%)$ & \\
\hline \multicolumn{5}{|c|}{ Seminal vesicle invasion } \\
\hline+ & $8(9.4 \%)$ & $4(6.9 \%)$ & $4(9 \%)$ & 0.39 \\
\hline- & $77(90.6 \%)$ & $37(93.1 \%)$ & $40(91 \%)$ & \\
\hline \multicolumn{5}{|c|}{ Gleason score } \\
\hline 6 & $44(51.7 \%)$ & $21(51.2 \%)$ & $23(52.3 \%)$ & \\
\hline 7 & $12(14.2 \%)$ & $4(9.8 \%)$ & $8(18.2 \%)$ & 0.03 \\
\hline $8-10$ & $29(34.1 \%)$ & $16(39.0 \%)$ & $13(29.5 \%)$ & \\
\hline \multicolumn{5}{|l|}{ PSA } \\
\hline$<4$ & $5(5.9 \%)$ & $4(9.8 \%)$ & $1(2.3 \%)$ & \\
\hline $4-20$ & $52(61.2 \%)$ & $24(58.5 \%)$ & $28(63.6 \%)$ & 0.88 \\
\hline$\geq 20$ & $28(32.9 \%)$ & $13(31.7 \%)$ & $15(34.1 \%)$ & \\
\hline
\end{tabular}

NLR: Neutrophil to lymphocyte ratio, PSA: Prostate specific antigen 
Table 2. Association of preoperative platelet to lymphocyte ratio with clinicopathological characteristics and bone metastases of prostate cancer

\begin{tabular}{|c|c|c|c|c|}
\hline & Total $(n=85)$ & $P L R<125.69$ & $P L R \geq 125.69$ & $\mathrm{p}$ \\
\hline \multicolumn{5}{|c|}{ Bone scintigraphy } \\
\hline+ & $36(42.4 \%)$ & $17(41.5 \%)$ & $19(43.2 \%)$ & 0.87 \\
\hline- & $49(57.6 \%)$ & $24(59.5 \%)$ & $25(56.8 \%)$ & \\
\hline \multicolumn{5}{|c|}{ Extraprostatic invasion } \\
\hline+ & $24(28.2 \%)$ & $8(19.5 \%)$ & $16(36.4 \%)$ & 0.85 \\
\hline- & $61(71.8 \%)$ & $33(80.5 \%)$ & $28(63.6 \%)$ & \\
\hline \multicolumn{5}{|c|}{ Perineural invasion } \\
\hline+ & $50(58.8 \%)$ & $21(51.2 \%)$ & $29(65.9 \%)$ & 0.16 \\
\hline- & $35(41.2 \%)$ & $20(48.8 \%)$ & $15(34.1 \%)$ & \\
\hline \multicolumn{5}{|c|}{ Positive resection margin } \\
\hline+ & $13(15.3 \%)$ & $5(12.2 \%)$ & $8(18.2 \%)$ & 0.44 \\
\hline- & $72(84.7 \%)$ & $36(87.8 \%)$ & $36(81.8 \%)$ & \\
\hline \multicolumn{5}{|c|}{ Seminal vesicle invasion } \\
\hline+ & $8(9.4 \%)$ & $4(44.8 \%)$ & $4(9 \%)$ & 0.91 \\
\hline- & 77 (90.6\%) & $37(55.2 \%)$ & $40(91 \%)$ & \\
\hline \multicolumn{5}{|c|}{ Gleason score } \\
\hline 6 & $44(51.7 \%)$ & $21(51.2 \%)$ & $23(52.3 \%)$ & \\
\hline 7 & $12(14.2 \%)$ & $4(9.8 \%)$ & $8(18.2 \%)$ & 0.40 \\
\hline $8-10$ & $29(34.1 \%)$ & $16(39.0 \%)$ & $13(29.5 \%)$ & \\
\hline \multicolumn{5}{|l|}{ PSA } \\
\hline$<4$ & $5(5.9 \%)$ & $4(9.8 \%)$ & $1(2.3 \%)$ & \\
\hline $4-20$ & $52(61.2 \%)$ & $24(58.5 \%)$ & $28(63.6 \%)$ & 0.34 \\
\hline$\geq 20$ & $28(32.9 \%)$ & $13(31.7 \%)$ & $15(34.1 \%)$ & \\
\hline
\end{tabular}

PLR: Platelet to lymphocyte ratio, PSA: Prostate specific antigen

have investigated the value of PLR in differentiation between benign prostate hyperplasia (BPH) and $\mathrm{PCa}$. In the Yüksel and Kaynar studies, the PLR values in patients with PCa were found to be significantly higher than in those with BPH ( $p=0.018$ and $\mathrm{p}=0.044$, respectively). Langsenlehner et al. (24) have also found that PLR could be used as a prognostic indicator in patients with prostate carcinoma receiving radiotherapy. However in our study, there was no correlation between PLR and histopathological features, PSA and bone metastasis. Possibly, the limited number of data and patient characteristics might be responsible for this observation.

In clinical practice, the prognostic risk in $\mathrm{PCa}$ is determined using Gleason score, PSA value and t-stage. According to the European Association of Urology (EAU) guidelines, the Gleason score in the risk classification is grouped as $<7,7,8-10$ (16). In our study, we analyzed the Gleason score by categorizing according to the EAU guidelines and found no statistically significant relationship between PLR and high Gleason score.
Table 3. Association of preoperative NMR with clinicopathological characteristics and bone metastases of prostate cancer

\begin{tabular}{|c|c|c|c|c|}
\hline & Total $(n=85)$ & $\mathrm{NMR}<8.38$ & $\mathrm{NMR} \geq 8.38$ & $\mathrm{p}$ \\
\hline \multicolumn{5}{|c|}{ Bone scintigraphy } \\
\hline+ & $36(42.4 \%)$ & $19(45.2 \%)$ & $17(39.5 \%)$ & 0.59 \\
\hline- & $49(57.6 \%)$ & $23(54.8 \%)$ & $26(60.9 \%)$ & \\
\hline \multicolumn{5}{|c|}{ Extraprostatic invasion } \\
\hline+ & $24(28.2 \%)$ & $10(23.8 \%)$ & $14(32.5 \%)$ & 0.37 \\
\hline- & $61(71.8 \%)$ & $32(76.2 \%)$ & $29(68.5 \%)$ & \\
\hline \multicolumn{5}{|c|}{ Perineural invasion } \\
\hline+ & $50(58.8 \%)$ & $25(59.5 \%)$ & $25(58.1 \%)$ & 0.89 \\
\hline- & $35(41.2 \%)$ & $17(40.5 \%)$ & $18(41.9 \%)$ & \\
\hline \multicolumn{5}{|c|}{ Positive Resection Margin } \\
\hline+ & $13(15.3 \%)$ & $6(14.2 \%)$ & $7(16.3 \%)$ & 0.79 \\
\hline- & $72(84.7 \%)$ & $36(85.8 \%)$ & $36(83.7 \%)$ & \\
\hline \multicolumn{5}{|c|}{ Seminal vesicle invasion } \\
\hline+ & $8(9.4 \%)$ & $4(9.5 \%)$ & $4(9.3 \%)$ & 0.97 \\
\hline- & $77(90.6 \%)$ & $38(90.5 \%)$ & $39(90.7 \%)$ & \\
\hline \multicolumn{5}{|c|}{ Gleason score } \\
\hline 6 & $44(51.7 \%)$ & $19(45.3 \%)$ & $25(58.1 \%)$ & \\
\hline 7 & $12(14.2 \%)$ & $5(11.9 \%)$ & $7(16.3 \%)$ & 0.20 \\
\hline $8-10$ & $29(34.1 \%)$ & $18(42.8 \%)$ & $11(25.6 \%)$ & \\
\hline \multicolumn{5}{|l|}{ PSA } \\
\hline$<4$ & $5(5.9 \%)$ & $2(4.7 \%)$ & $3(7 \%)$ & \\
\hline $4-20$ & $52(61.2 \%)$ & $21(50 \%)$ & $31(72 \%)$ & 0.06 \\
\hline$\geq 20$ & $28(32.9 \%)$ & $19(45.3)$ & $9(21 \%)$ & \\
\hline
\end{tabular}

NMR: Neutrophil to monocyte ratio, PSA: Prostate specific antigen

Also we did not find a significant relationship between high PSA and PLR values and the presence of metastases on BS. Similarly, in their study including 290 patients with PCa Wang et al. (16) determined a cut-off value of 117.58 for PLR calculated by Roc curve analysis and found no significant difference in serum PSA, Gleason score and incidence of metastasis between low and high PLR patients. Also there are studies focusing on the relationship between NMR and cancer prognosis. One of them, published by Bobdey and colleagues, is a large clinical series including 471 patients with oral cavity cancer (25). They have found a significant difference in the 5-year survival between patients with low and high monocyte count ( $43.9 \%$ and $55.4 \%$, respectively; $p<0.001$ ). Moreover, Ceylan et al. (26) indicated that high NLR and NMR can be used for the decision for repeating the biopsy in patients whose initial biospy is negative despite persistence of high PSA values. Cihan et al. (27) found that NMR was higher in patients with PCa than in patients with $\mathrm{BPH}$, but this elevation was not statistically significant. In our study, there was no correlation of NMR with histopathological features, bone metastasis and PSA. 
The difference from these studies may be due to the low number of patients in our study and the variability of the disease stage in the patient population. We also investigated the relationship between clinicopathological features of PCa, such as Gleason scores, presence of extraprostatic invasion, perineural invasion, positive margin resection, seminal vesicle invasion, and NLR, PLR and NMR. In fact, only a statistically significant relationship was found between high NLR and high Gleason score. It is considered that this study has some limitations related to a limited number of patients and retrospective study designs and larger patient series and clinical trials are needed.

In conclusion, despite the limited number of patients, our results indicate that NLR is significantly high in patients with metastatic bone disease on bone scan. This relationship was also supported by high NLR and high Gleason score which is accepted as a risk factor for poor prognosis of PCa. We suggest that further studies in large series are essential to assess the value of high NLR values in clinical use to detect advanced stage PCa patients.

\section{Ethics}

Ethics Committee Approval: The study was approved by the Ege University of Local Ethics Committee (approval number: 1712.1/36).

Informed Consent: Retrospective study.

\section{Authorship Contributions}

Concept: Y.C., Z.Ö., Design: Y.C., Z.Ö., Data Collection and/or Processing: S.T., S.Ş., B.S., Analysis and/or Interpretation: Y.C., S.T., Z.Ö., Literature Research: Y.C., Writing: Y.C., Z.Ö.

Conflict of Interest: There is no conflict of interest related with this manuscript.

Financial Disclosure: The authors declared that this study received no financial support.

\section{References}

1. Coussens LM, Werb Z. Inflammation and cancer. Nature 2002;420:860.

2. Guthrie GJ, Charles KA, Roxburgh CS, Horgan PG, McMillan DC, Clarke SJ. The Systemic inflammation-based neutrophil-lymphocyte ratio: experience in patients with cancer. Crit Rev Oncol Hematol 2013;88:218-230.

3. Luo Y, She DL, Xiong H, Fu SJ, Yang L. Pretreatment Neutrophil to Lymphocyte Ratio as a Prognostic Predictor of Urologic Tumors: A Systematic Review and Meta-Analysis. Medicine (Baltimore) 2015;94:e1670.

4. Mantovani A, Allavena P, Sica A, Balkwill F. Cancer related inflammation. Nature 2008;454:436-444.

5. Stock D, Groome PA, Siemens DR. Inflammation and prostate cancer: A future target for prevention and therapy. Urol Clin North Am 2008;35:117130.

6. Sciarra A, Gentilucci A, Salciccia S, Pierella F, Del Bianco F, Gentile V, Silvestri I, Cattarino $S$. Prognostic value of inflammation in prostate cancer progression and response to therapeutic: a critical review. J Inflamm (Lond) 2016;13:35

7. Parikh S, Murray L, Kenning L, Bottomley D, Din O, Dixit S, Ferguson C Handforth C, Joseph L, Mokhtar D, White L, Wright G, Henry AM. Real-world Outcomes and Factors Predicting Survival and Completion of Radium 223 in Metastatic Castrate-resistant Prostate Cancer. Clin Oncol (R Coll Radiol) 2018;30:548-555.

8. National Cancer Institute. SEER Cancer Stat Facts: prostate cancer. 2017 http://seer.cancer.gov/statfacts/html/prost.html.

9. Grivennikov SI, Greten FR, Karin M. Cell Immunity, Inflammation and Cancer. Cell 2010;140:883-899.

10. Kawahara T, Fukui S, Sakamaki K, Ito $Y$, Ito H, Kobayashi N, Izumi K, Yokomizo Y, Miyoshi Y, Makiyama K, Nakaigawa N, Yamanaka T, Yao M, Miyamoto H, Uemura $\mathrm{H}$. Neutrophil-to lymphocyte ratio predicts prostatic carcinoma in men undergoing needle biopsy. Oncotarget 2015;6:32169-32176.

11. Wang J, Liu $Y$, Zhang N, Li X, Xin P, Bi J, Kong C. Prognostic role of pretreatment platelet to lymphocyte ratio in urologic cancer. Oncotarget 2017;8:70874-70882.

12. Kitayama J, Yasuda K, Kawai K, Sunami E, Nagawa H. Circulating lymphocyte is an important determinant of the effectiveness of preoperative radiotherapy in advanced rectal cancer. BMC Cancer 2011;11:64.

13. Mahmoud SM, Paish EC, Powe DG, Macmillan RD, Grainge MJ, Lee AH, Ellis I0, Green AR. Tumor-infiltrating CD8+lymphocytes predict clinical outcome in breast cancer. J Clin Oncol 2011;29:1949-1955.

14. Luo Y, She DL, Xiong H, Fu SJ, Yang L. Pretreatment neutrophil to lymphocyte ratio as a prognostic predictor of urologic tumors: a systematic review and meta-analysis. Medicine 2015;94:1670.

15. Cao J, Zhu X, Zhao X, Li XF, Xu R. Neutrophil-to-lymphocyte ratio predicts PSA response and prognosis in prostate cancer: a systematic review and meta-analysis. PLoS One 2016;11:0158770.

16. Wang $Y, X u$ F, Pan J, Zhu $Y$, Shao $X$, Sha J, Wang Z, Cai $Y$, Liu Q, Dong B, Xue $W$, Huang $Y$. Platelet to lymphocyte ratio as an independent prognostic indicator for prostate cancer patients receiving androgen deprivation therapy. BMC Cancer 2016;24;16:329.

17. Kawahara $T$, Yokomizo $Y_{\text {, Ito }} Y_{\text {, Ito }} H_{\text {, Ishiguro } H}$, Teranishi J, Makiyama $K$, Miyoshi $Y$, Miyamoto $H$, Yao M, Uemura $H$. Pretreatment neutrophil-tolymphocyte ratio predicts the prognosis in patients with metastatic prostate cancer. BMC Cancer 2016;16:111.

18. Sonpavde G, Pond GR, Armstrong AJ, Clarke SJ, Vardy JL, Templeton AJ, Wang SL, Paolini J, Chen I, Chow-Maneval E, Lechuga M, Smith MR, Michaelson MD. Prognostic impact of the neutrophil-to-lymphocyte ratio in men with metastatic castration-resistant prostate can $\neg$ cer. Clin Genitourin Cancer 2014;12:317-324

19. Wang S, Zhang Z, Fang F, Gao X, Sun W, Liu H. The neutrophil/lymphocyte ratio is an independent prognostic indicator in patients with bone metastasis. Oncol Lett 2011;2:735-740.

20. Maeda $Y$, Kawahara $T$, Koizumi M, Ito $H$, Kumano $Y$, Ohtaka $M$, Kondo $T$ Mochizuki T, Hattori Y, Teranishi J, Yumura Y, Miyoshi Y, Yao M, Miyamoto $\mathrm{H}$, Uemura H. Lack of an Association between Neutrophil-to-Lymphocyte Ratio and PSA Failure of Prostate Cancer Patients Who Underwent Radical Prostatectomy. Biomed Res Int 2016;2016:6197353.

21. Li $F, H u H, G u S$, Chen $X$, Sun 0 . Platelet to lymphocyte ratio plays an important role in prostate cancer's diagnosis and prognosis. Int J Clin Exp Med 2015; 8(7):11746-11751.

22. Kaynar M, Yildirim ME, Gul M, Kilic O, Ceylan K, Goktas S. Benign prostatic hyperplasia and prostate cancer differentiation via platelet to lymphocyte ratio. Cancer Biomark 2015;15:317-23.

23. Yuksel $\mathrm{OH}$, Urkmez $\mathrm{A}$, Akan $\mathrm{S}$, Yıldirim $\mathrm{C}$, Verit A. Predictive value of the platelet-to-lymphocyte ratio in diagnosis of prostate cancer. Asian Pac J Cancer Prev 2015;16:6407-6412. 
24. Langsenlehner T, Pichler M, Thurner EM, Krenn-Pilko S, Stojakovic T, Gerger A, Langsenlehner U. Evaluation of the platelet-to-lymphocyte ratio as a prognostic indicator in a European cohort of patients with prostate cancer treated with radiotherapy. Urol Oncol 2015;33:201.e9-16.

25. Bobdey S, Ganesh B, Mishra P, Jain A. Role of Monocyte Count and Neutrophil-to-Lymphocyte Ratio in Survival of Oral Cancer Patients. Int Arch Otorhinolaryngol 2017;21:21-27.
26. Ceylan Y, Günlüsoy B, Değirmenci T, Bolat D, Kozacıoglu Z, Vardar E, Topçu YK, Polat S. Neutrophil-to-lymphocyte and neutrophil-to-monocyte rates in the decision for a prostate re-biopsy in patients with a previous benign pathology and consistently 2,5-10 ng/ml PSA value. Arch Esp Urol 2016;69:627-635.

27. Cihan YB, Arslan A, Ergul MA. Subtypes of White Blood Cells in Patients with Prostate Cancer or Benign Prostatic Hyperplasia and Healthy Individuals. Asian Pac J Cancer Prev 2013;14:4779-4783. 